\title{
SUPERCONDUCTING PROPERTIES OF RAPIDLY QUENCHED AND HEAT TREATED Zr-V AND Hf-V FOILS
}

\author{
M. Tenhover
}

SEPTEMBER 1979

\section{A REPORT ON RESEARCH CONDUCTED UNDER CONTRACT FOR THE DEPARTMENT OF ENERGY}

\section{W. M. KECK LABORATORY OF} ENGINEERING MATERIALS

\section{CALIFORNIA INSTITUTE OF TECHNOLOGY \\ PASADENA}




\section{DISCLAIMER}

This report was prepared as an account of work sponsored by an agency of the United States Government. Neither the United States Government nor any agency Thereof, nor any of their employees, makes any warranty, express or implied, or assumes any legal liability or responsibility for the accuracy, completeness, or usefulness of any information, apparatus, product, or process disclosed, or represents that its use would not infringe privately owned rights. Reference herein to any specific commercial product, process, or service by trade name, trademark, manufacturer, or otherwise does not necessarily constitute or imply its endorsement, recommendation, or favoring by the United States Government or any agency thereof. The views and opinions of authors expressed herein do not necessarily state or reflect those of the United States Government or any agency thereof. 


\section{DISCLAIMER}

Portions of this document may be illegible in electronic image products. Images are produced from the best available original document. 
California Institute of Technology

W. M. Keck Laboratory of Engineering Materials

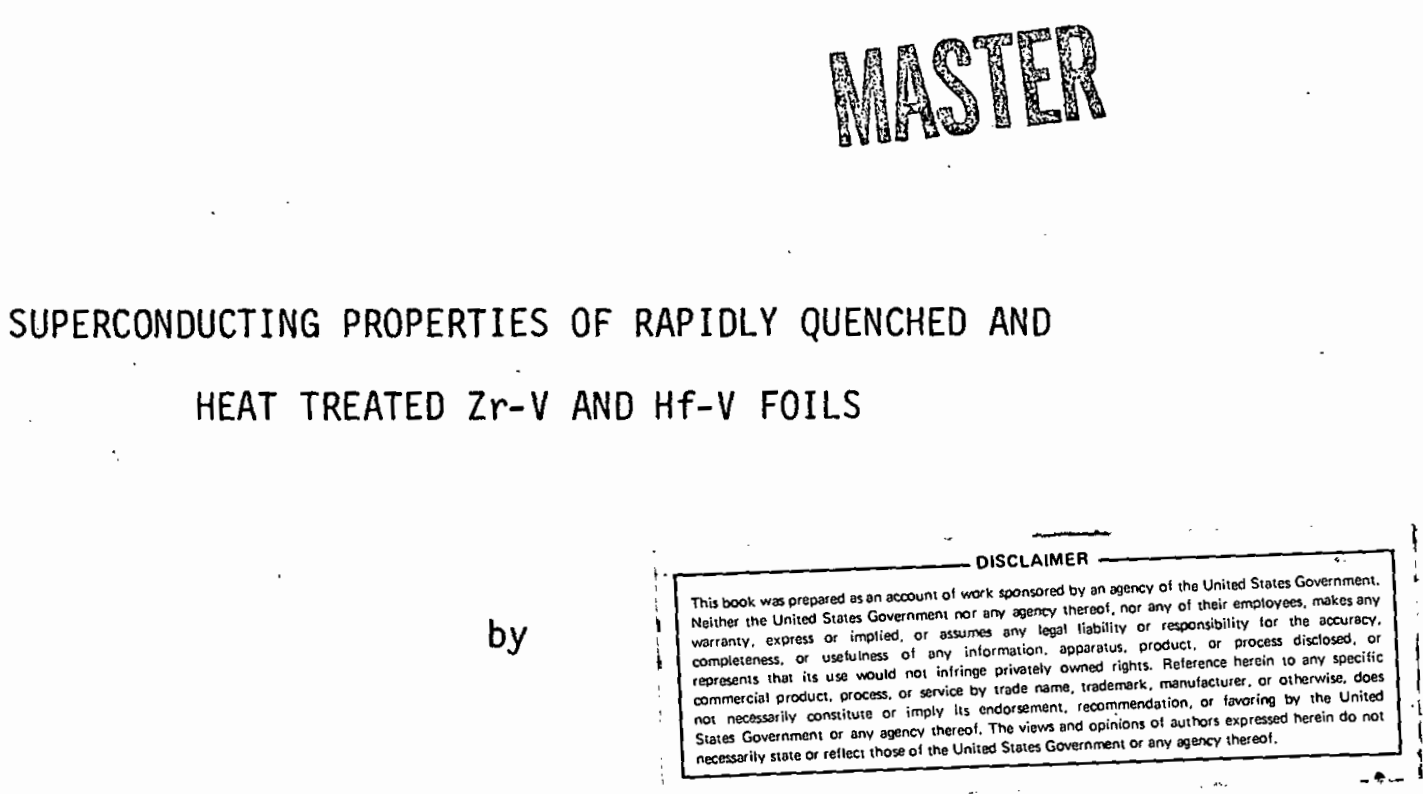

M. Tenhover

Department of Energy Report No. 98, under Contract No. DE-ACO3-76ER00822.

Professor W. L. Johnson, principal investigator. 
This report was prepared as an account of work sponsored by the United States Government. Neither the United States nor the Department of Energy, nor any of their employees, nor any of their contractors, subcontractors, or their employees, makes any warranty, express or implied, or assumes any legal liability or responsibility for the accuracy, completeness or usefulness of any information, apparatus, product or process disclosed, or represents that its use would not infringe privately-owned rights. 


\section{ABSTRACT}

The results of rapid quenching and subsequent heat treatments on the superconducting properties of the $\mathrm{Zr}-\mathrm{V}$ and $\mathrm{Hf}-\mathrm{V}$ binary systems are presented. Metaliic glasses can be prepared in these systems which have very attractive properties for practical application. The existence of a flexible glassy phase raises the prospect of alternative methods for the construction of superconducting devices. As-quenched, partially crystalline material is characterized by small critical currents, yet relatively large upper critical fields and transition temperatures. Heat treatments considerably enhance the current carrying capability. 
INTRODUCTION

Since the discovery of superconductivity in the Laves phase compound $\mathrm{ZrV}_{2}$ by Matthias et al [1] and the illumination of the exceptional properties of $\mathrm{Hf}_{0.5} \mathrm{Zr}_{0.5} \mathrm{~V}_{2}$ by Inoue et al [2], the $\mathrm{C}-15$ class of materials have been of great interest. From a practical standpoint, Inoue et al found for example that in the ternary system $\mathrm{Hf}-\mathrm{Zr}-\mathrm{V}$, very large critical fields $\left(\mathrm{H}_{\mathrm{C} 2}>200 \mathrm{kOe}\right)$ and high critical currents $\left(\mathrm{J}_{\mathrm{C}}>10^{5} \mathrm{~A} / \mathrm{cm}^{2}\right.$ at $4.2^{\circ} \mathrm{K}$ and $H_{\text {ext }}=130 \mathrm{kOe}$ ) could be obtained. It has also been demonstrated by Brown et al [3] that for $\mathrm{HfV}_{2}$ unlike the A- 15 compounds and Chevral phases the superconducting properties are not substantialily degraded by exposure to fast neutrons [4]. These materials, therefore possess desirable characteristics for practical applications. As is the case for many materials which possess excellent superconducting properties, the Laves phase compounds are characteristically very brittle. The nature of the applications one imagines for these materials along with the A-15 compounds $\left(\mathrm{Nb}_{3} \mathrm{Sn}, \mathrm{V}_{3} \mathrm{Ga}\right)$ requires that at some point in the fabrication process the materials display a considerable amount of mechanical flexibility.

Two methods for the construction of high field, high current superconducting devices presently being explored involve the use of composites [5-7] and metallic glasses. Composites are formed by incorporating the superconducting materials $\left(\mathrm{Nb}_{3} \mathrm{Sn}\right.$ or $\mathrm{V}_{3} \mathrm{Ga}$ ) in a matrix which has good mechanical properties, usually copper. This method has met with

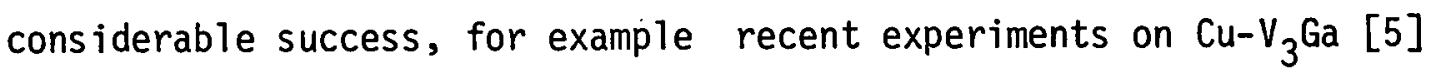
composites have shown that for this material $\mathrm{H}_{\mathrm{c} 2}\left(4.2^{\circ} \mathrm{K}\right)=224 \mathrm{k} 0 \mathrm{e}$, $T_{C}=15.5^{\circ} \mathrm{K}$, and $J_{C}\left(4.2^{\circ} \mathrm{K}\right)=2 \times 10^{5} \mathrm{~A} / \mathrm{cm}^{2}$ at $\mathrm{H}_{\text {ext }}=40 \mathrm{k} 0 \mathrm{e}$. The metallic 
glasses containing $4 \mathrm{~d}$ and $5 \mathrm{~d}$ transition metals [8-9] are somewhat unique high field superconducting materials in that they frequently exhibit excellent mechanical properties. Furthermore, recently there has been indications that they are highly resistant to damage by high energy neutrons [10].

In this investigation, I report the results of rapidly quenching $\mathrm{Zr}-\mathrm{V}$ and $\mathrm{Hf}-\mathrm{V}$ alloys. It is possible to prepare metallic glasses in these systems which possess very desirable mechanical properties. The nature of superconductivity and possible application and fabrication methods are discussed.

EXPERIMENTAL

Alloys were prepared by levitation melting in an Argon atmosphere of 99.99\% pure Vandium, $99.9 \%$ pure Zirconium (1.2\% H.f) and $99.9 \%$ pure Hafnium $(2 \% \mathrm{Zr})$. Of primary importance in the preparation of the alloys is the exclusion of 0xygen. This was especially true for the alloys with higher $V$ content. The ingots were repeatedly broken open and remelted to insure homogeneity. Weight loss after the first melt was typically less than $1 \mathrm{mg}$ in a 2 gram ingot, and the compositions reported are the nominal ones. The samples were rapidly quenched into circular foils approximately $1 \mathrm{~cm}$ in diameter and $30 \mu \mathrm{m}$ thick by splat cooling [11] in a Helium atmosphere. Material quenched without paying strict attention to the exclusion of 0xygen resulted in brittle foils, frequently not amorphous. Similar behavior has also been observed in the $\mathrm{Ti}-\mathrm{Ni}$ metallic glass system [12].

The nature of the as-quenched and heat treated foils was characterized 
by conventional $x$-ray diffraction methods. The foils were classified amorphous when the $x$-ray intensity as a function of diffraction angle showed a smooth featureless band.

The superconducting transition temperatures were measured both inductively $\left(T_{c}^{i n d}\right)$ using an ac bridge circuit and resistively $\left(T_{c}^{R}\right)$ using a standard four point probe. From these measurements, values for the onset of superconductivity as well as the midpoint of the transition were extracted. Values for several compositions of as-quenched foils are detailed in Table $I$. The upper critical magnetic field $H_{c 2}(T)$ was measured by fixing the applied field normal to the direction of current flow in the sample and finding the temperature at which the resistivity reached half its normal value.

Samples for critical current $\left(J_{c}\right)$ measurements were prepared by spot-welding pure gold pads to strips cut from the quenched foils. These samples were then sealed in evacuated quartz ampoules and heat treated at various temperatures for 24 hours as detailed in Table II. The samples were attached to the $J_{c}$ probe by soldering the gold pads to two large copper bars. Both the sample and the copper bars were submerged in liquid helium $\left(4.2^{\circ} \mathrm{K}\right)$. $J_{c}$ was taken to be the current at which a measurable voltage $(1 \mu V)$ appeared across the sample. For several samples an external magnetic field from a $40 \mathrm{kOe} \mathrm{Nb}-\mathrm{Ti}$ superconducting magnet was applied normal to the direction of current flow.

RESULTS AND DISCUSSION

An amorphous phase was found to be obtainable by splat cooling over a fairly broad range for both the $\mathrm{Z} r-\mathrm{V}$ and $\mathrm{Hf}-\mathrm{V}$ systems. Single phase 
TABLE I. Superconducting transition temperature for as-quenched Zr-Hf-V foils.

\begin{tabular}{|c|c|c|c|c|}
\hline SAMPLE & $\begin{array}{c}\mathrm{T}_{\mathrm{C}}{ }^{\text {ind }}\left({ }^{\circ} \mathrm{K}\right) \\
\text { ONSET }\end{array}$ & $\begin{array}{c}\mathrm{T}_{C}{ }^{\text {ind }}\left({ }^{\circ} \mathrm{K}\right) \\
\frac{1}{2} \text { point }\end{array}$ & $\begin{array}{l}T_{C}{ }^{R}\left({ }^{\circ} K\right) \\
\frac{1}{2} \text { point }\end{array}$ & PHASES PRESENT ${ }^{\star}$ \\
\hline $\mathrm{Zr}_{70} \mathrm{v}_{30}$ & 8.4 & 5.0 & 6.6 & $h c p, b c c, Z r V_{2}$ \\
\hline $\mathrm{Zr}_{64} \mathrm{~V}_{36}$ & 9.05 & 6.7 & 8.4 & hcp, amorphous, bcc, $Z r V_{2}$ \\
\hline $\mathrm{Zr}_{62} \mathrm{v}_{38}$ & 9.0 & 4.4 & 5.2 & amorphous, hcp, bcc, $\mathrm{ZrV}_{2}$ \\
\hline $\mathrm{Zr}_{60} \mathrm{~V}_{40}$ & & $<2.0$ & $<2.0$ & amorphous \\
\hline $\mathrm{Zr}_{55} \mathrm{~V}_{45}$ & 7.5 & 4.9 & 5.6 & amorphous, $\mathrm{ZrV}_{2}$, bcc, hcp \\
\hline $\mathrm{ZrV}_{2}$ & 9.3 & 8.2 & 8.2 & $\mathrm{ZrV}$, hcp, amorphous \\
\hline $\mathrm{Hf}_{62} \mathrm{~V}_{38}$ & 9.2 & 6.9 & 7.2 & amorphous, hcp, bcc, $\mathrm{HfV}_{2}$ \\
\hline $\mathrm{HF}_{60} \mathrm{~V}_{40}$ & & $<2.0$ & $<2.0$ & amorphous \\
\hline
\end{tabular}

* The order of the phases is an indication of the relative amounts of each phase present. E.g. $Z r_{70} V_{30}$ is primarily hcp, some bcc, and a trace of $\mathrm{ZrV}_{2}$. 
amorphous material was obtained from $38 \%$ to $45 \% \mathrm{~V}$. The $\mathrm{x}$-ray patterns for these samples displayed a smooth broad band characteristic of metallic glasses. Below this region the as-quenched foils were found to consist of a combination of amorphous material, $h c p \operatorname{Zr}\left(H_{f}\right)$, bcc solid solution of $\operatorname{Zr}(\mathrm{Hf})$ and $V$, and the Laves phases $\operatorname{Zr}(\mathrm{Hf}) \mathrm{V}_{2}$. Above $45 \% \mathrm{~V}$ the foils consisted primarily of a mixture of $\mathrm{Zr}(\mathrm{Hf}) \mathrm{V}_{2}$ and an amorphous phase. The Bragg peaks associated with these phases were unusually broad indicating small crystal sizes. The foils were found to be at least partially amorphous from $34 \%$ to $66 \% \mathrm{~V}$.

A considerable amount of work has been done on various $\mathrm{Zr}$-based metallic glasses, primarily of the form Zr-LTM (LTM-late transition metals such as $\mathrm{Pd}, \mathrm{Rh}, \mathrm{Cu}$, or $\mathrm{Ni}$ ). The $\mathrm{Zr}-\mathrm{V}$ and $\mathrm{Hf}-\mathrm{V}$ glasses uncovered in the present study are in a sense quite unique in that both components are early transition metals. Preliminary results on their electrical and thermal properties indicate that they are very similar to the more conventional $\mathrm{Zr}$-LTM glasses. An interesting fact discovered in this investigation is that the glass forming ability is strongly enhanced with small additions of $\mathrm{Be}$ and strongly degraded by small additions of $\mathrm{Cu}$ or $\mathrm{Ni}$. This may suggest that the structure of the $\mathrm{Zr}-\mathrm{V}$ and $\mathrm{Hf}-\mathrm{V}$ glasses is closer to that of the $\mathrm{Zr}$-Be glass than that of the $\mathrm{Zr}$-Cu glass. A comprehensive study is now in progress on the properties and structure of the $\mathrm{Zr}-\mathrm{V}$ and $\mathrm{Hf}-\mathrm{V}$ glasses.

Superconductivity in the rapidly quenched materials, like the corresponding equilibrium alloys is highly dependent on the presence of the Laves phase compounds $\mathrm{ZrV}_{2}$ and $\mathrm{HfV}_{2}$. Amorphous $\mathrm{Zr}_{60} \mathrm{~V}_{40}$ and $\mathrm{Hf}_{60} \mathrm{~V}_{40}$ were not found to be superconducting down to $2^{\circ} \mathrm{K}$. Previous work [13] on hcp $\mathrm{Zr}-\mathrm{V}$ and $\mathrm{Hf}-\mathrm{V}$ as well as the corresponding bcc solid solution 
has shown that they are not superconducting down to $4.2^{\circ} \mathrm{K}$. It is difficult here to fix a value for $T_{c}$ of the hcp or bcc phases since for all partially crystalline alloys quenched, some $\mathrm{Zr}(\mathrm{Hf}) \mathrm{V}_{2}$ was formed, complicating the analysis of the $T_{c}$ data. The small value for $J_{c}(H=0)$ at $4.2^{\circ} \mathrm{K}$ (Table II), yet relatively high $T_{C}^{R}$ for a $Z r_{70} V_{30}$ foil which consisted of hcp, bcc, and a trace of $Z_{2 V}$ strongly suggest that the only supercurrent carrying phase present at $4.2^{\circ} \mathrm{K}$ is $\mathrm{ZrV}_{2}$.

The $T_{c}$ values measured for the as-quenched materials have the same basic features. The onset values measured inductively are all close to the $T_{c}$ of the Laves phase compound $\mathrm{Zr}(\mathrm{Hf}) \mathrm{V}_{2}$. A slight depression of $\mathrm{T}_{\mathrm{C}}$ occurs in those samples in which a sizable fraction of the sample is not superconducting. This is most noticeable for $2 r_{70} V_{30}$ (primarily hcp) and $Z r_{55} V_{45}$ (primarily amorphous). The widths of the transitions are all quite broad, reflecting the inhomogeneous nature of the samples. Superconductivity in the as-quenched foils can be understood as being due to the formation of the Laves phase compounds $\mathrm{Zr}(\mathrm{Hf}) \mathrm{V}_{2}$. Those samples in which little $\mathrm{Zr}(\mathrm{Hf}) \mathrm{V}_{2}$ was formed showed depressed $\mathrm{T}_{\mathrm{c}}$ values and especially broad transitions. This is to be expected as being the result of the proximity effect [14] for a microstructure in which the superconducting particles are separated by substantially more than a coherence length. $T_{c}^{R}$ is further depressed by the necessity of percolating a supercurrent path through the sample.

The data obtained from measuring $\mathrm{H}_{\mathrm{c} 2}$ of two as-quenched and two heat treated $\mathrm{Zr}(\mathrm{Hf})-\mathrm{V}$ foils is reproduced in Figure 1 . The heat treated, fully crystallized foils of $\mathrm{Hf}_{3} \mathrm{~V}_{2}$ and $\mathrm{Zr}_{3} \mathrm{~V}_{2}$ displayed $\mathrm{H}_{\mathrm{C} 2}$ vs $\mathrm{T}$ curves in excellent agreement with previous work [15] on the $\mathrm{HfV}_{2}$ and $\mathrm{ZrV}_{2}$ compounds. As mentioned before, the pure amorphous foils were not found to 


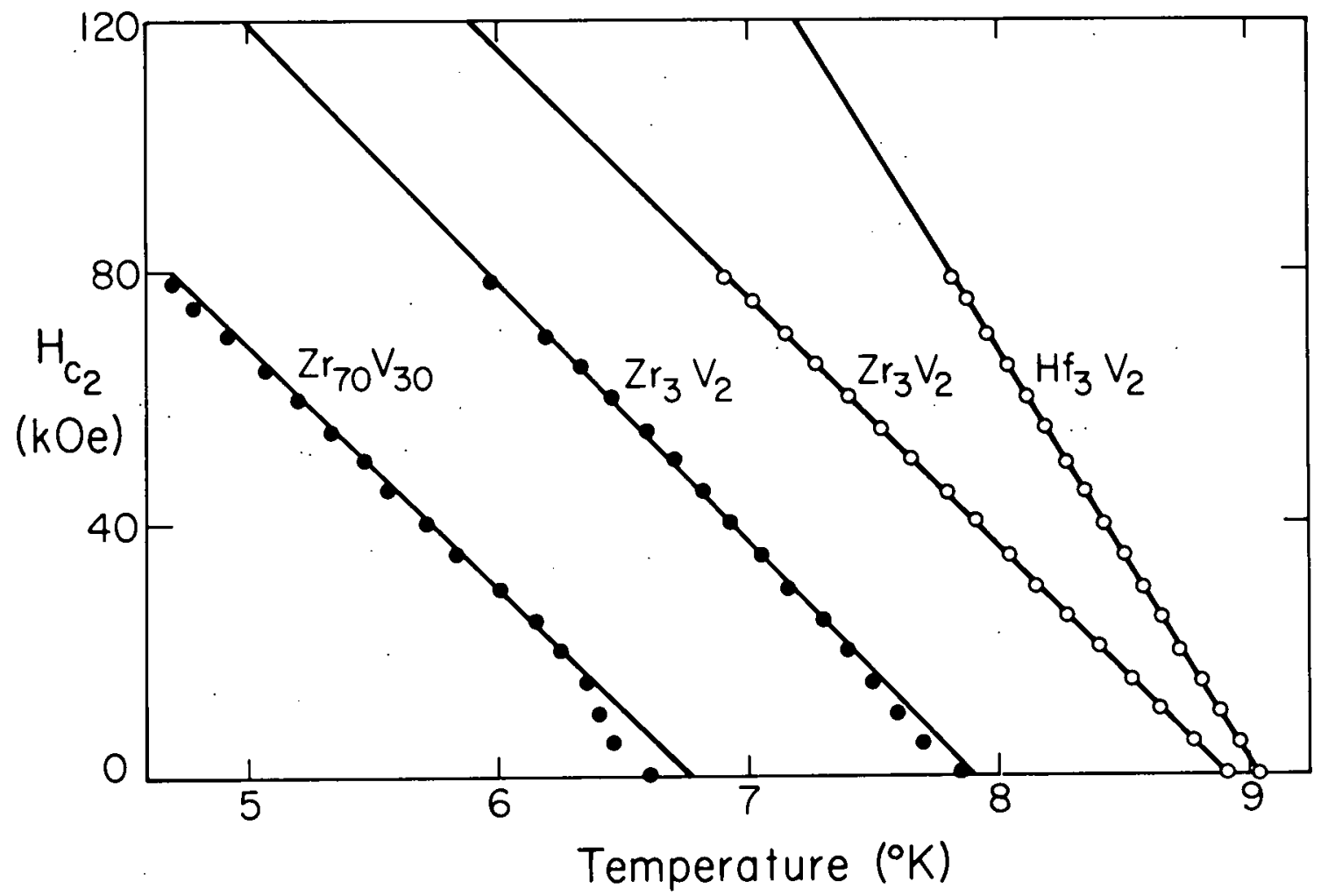

Fig. 1. Upper critical magnetic field as a function of temperature for several $\mathrm{Zr}-\mathrm{Hf}-\mathrm{V}$ foils. Open circles refer to fully crystallized foils and filled circles to as-quenched foils. The magnetic field is applied normal to the direction of current flow. 
be superconducting. Samples in which there was a small amount of crystalline $\mathrm{ZrV}_{2}$ are also shown in Figure 1. At high fields (>20 kOe) the as-quenched $Z r_{3} V_{2}$ and $Z r_{70} V_{30}$ samples have $H_{c 2}$ vs $T$ curves which are linear, having roughly the same slope as the fully crystallized $Z r_{3} V_{2}$ foil and as-cast $Z_{2} V_{2}$. This behavior was found for all compositions studied which exhibited superconductivity. Together with the $T_{c}$ data, this implies that $\mathrm{ZrV}_{2}$ and $\mathrm{HfV}_{2}$ formed as a result of rapid quenching retain the same superconducting characteristics they exhibit in as-cast alloys. The slight deviation from linearity near $T_{C}(H=0)$ and the depression of $T_{c}$ for the as-quenched samples again represents the difficulty in percolating a supercurrent through these materials.

Critical current measurements on as-quenched and annealed samples demonstrate the need for having a substantial amount of the Laves phases present in order to obtain large $J_{c}$ values. The results of the $J_{c}$ measurements at $4.2^{\circ} \mathrm{K}$ and zero applied magnetic field are listed in Table II. The measurements on $2 r_{60} \mathrm{~V}_{40}$ as a function of heat treatment show that good current carrying capacity can be obtained after a $500^{\circ} \mathrm{C}$, 24 hours treatment. The heat treatment parameters have not been extensively studied yet and some enhancement of $J_{C}$ can be expected by a better heat treatment sequence.

Figure 2 shows the results of the application of an external field to $J_{c}\left(4.2^{\circ} \mathrm{K}\right)$ for a fully crystallized $Z r_{55} V_{45}$ sample. The dependence with field for $J_{c}$ measured here is very similar to the result of Inoue et al. [2] on $\mathrm{Hf}_{0.5} \mathrm{Zr}_{0.5} \mathrm{~V}_{2}$. The somewhat smaller absolute values for $J_{c}$ measured here $\left(\sim 5 \times 10^{4}\right)$ compared to Inoue et al $\left(\sim 5 \times 10^{5}\right)$ is most probably a manifestation of the higher $V$ content as well as an indication that the annealing parameters are not yet optimal. A 
TABLE II. Critical current of as-quenched and heat treated $\mathrm{Zr}-\mathrm{V}$ foils.

\begin{tabular}{|c|c|c|}
\hline SAMPLE & HEAT TREATMENT & $\begin{array}{c}J_{C}(H=0) \text { at } 4.2^{\circ} \mathrm{K} \\
\left(\text { Amps } / \mathrm{cm}^{2}\right)\end{array}$ \\
\hline $\mathrm{Zr}_{70} \mathrm{v}_{30}$ & as-quenched & $1.8 \times 10$ \\
\hline $\mathrm{Zr}_{60} \mathrm{~V}_{40}$ & as-quenched & 0 \\
\hline $\mathrm{Zr}_{60} \mathrm{~V}_{40}$ & $200^{\circ} \mathrm{C}, 24$ hours & 0 \\
\hline $\mathrm{Zr}_{60} \mathrm{v}_{40}$ & $300^{\circ} \mathrm{C}, 24$ hours & $7.3 \times 10$ \\
\hline $2 r_{60} v_{40}$ & $400^{\circ} \mathrm{C}, 24$ hours & $8.7 \times 10^{3}$ \\
\hline $\mathrm{Zr}_{60} \mathrm{~V}_{40}$ & $500^{\circ} \mathrm{C}, 24$ hours & $2.3 \times 10^{4}$ \\
\hline $\mathrm{Zr}_{60} \mathrm{v}_{40}$ & $600^{\circ} \mathrm{C}, 24$ hours & $2.0 \times 10^{4}$ \\
\hline $\mathrm{Zr}_{55} \mathrm{~V}_{45}$ & $500^{\circ} \mathrm{C}, 24$ hours & $5.6 \times 10^{4}$ \\
\hline
\end{tabular}




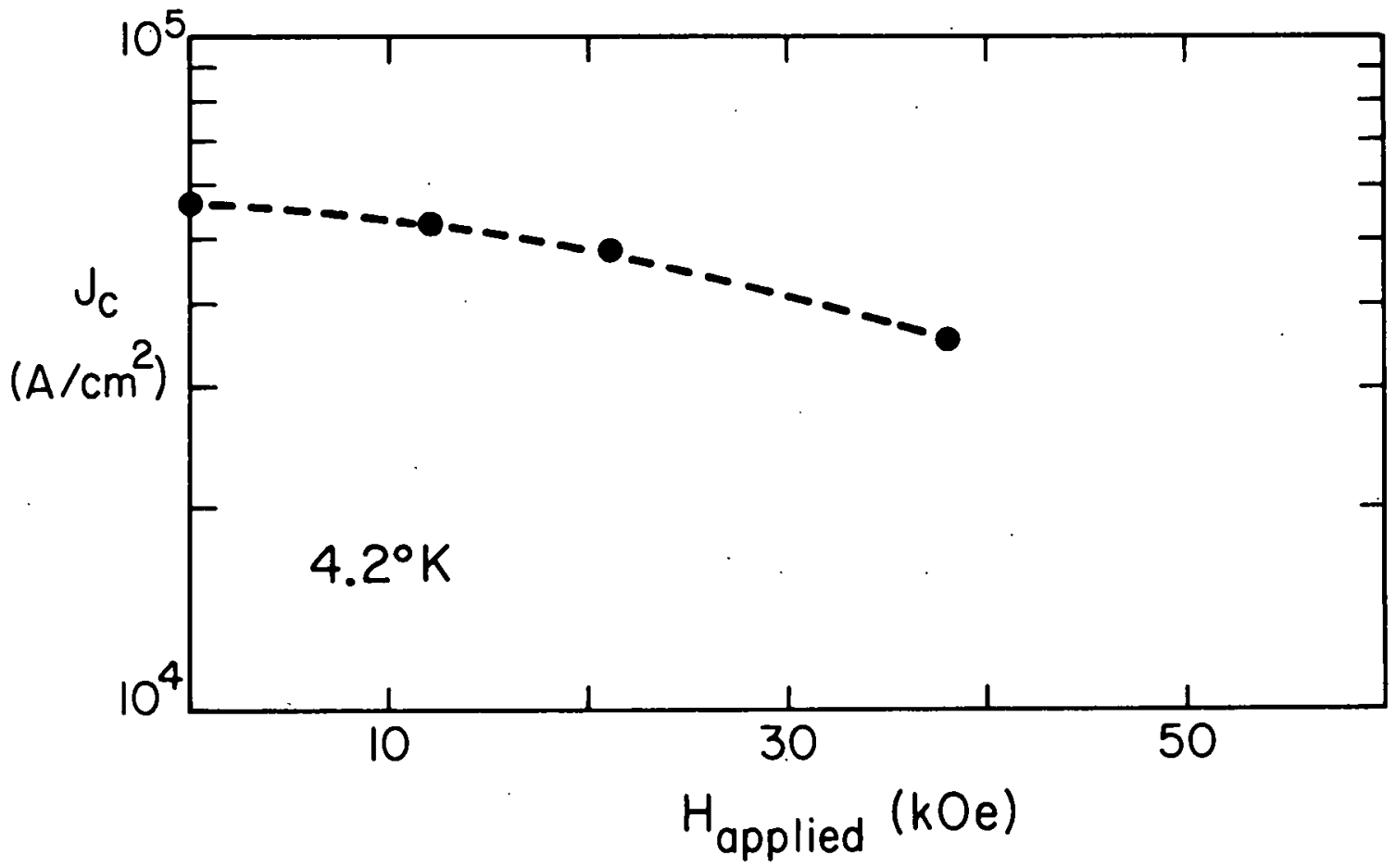

Fig. 2. Critical current at $4 \cdot 2^{\circ} \mathrm{K}$ as a function of magnetic field applied normal to the direction of current flow. The sample is a fully crystallized foil of $\mathrm{Zr}_{55} \mathrm{~V}_{45}$. 
detailed study of the formation and size of grains upon crystallization using an Electron Microscope as well as investigations into other flux pinning mechanisms is needed. It seems likely that with proper treatments these materials will have critical currents equal to or exceeding that reported by Inoue et al [2] for $\mathrm{Hf}_{0.5} \mathrm{Zr}_{0.5} \mathrm{~V}_{2}$.

$X$-ray analysis of heat treated $Z r-V$ foils indicates that heat treating at temperatures greater than $300^{\circ} \mathrm{C}$ eventually leads to the formation of $\mathrm{ZrV}_{2}$ ahd hcp $\mathrm{Zr}$. This is to be expected since these are the equilibrium phases for this system [16]. Similar to the as-quenched foils, the only supercurrent carrying phase in the heat treated foils is $\mathrm{ZrV}_{2}$. In terms of superconducting properties, the microstructures of the as-quenched and heat treated foils are similar. Both consist of a good superconducting compound $\left(\mathrm{ZrV}_{2}\right)$ dispersed in an essentially nonsuperconducting matrix. The rise in $J_{C}$ for heat treated $Z r_{60} V_{40}$ foils as the heat treating temperature is increased (Table II) is accompanied by an increase in the fraction of $\mathrm{ZrV}_{2}$ in the sample. The enhancement of $\mathrm{J}_{c}$ for heat treated foils observed is simply a consequence of having a larger fraction of $\mathrm{ZrV}_{2}$ in the samples.

The results reported in this paper show promise for practical application. The existence of a readily obtainable amorphous phase in these systems offers alternative means of fabricating superconducting lines, transformers, and magnets. As-quenched material from $\sim 38$ to $45 \% \mathrm{~V}$ was frequently found to be very flexible. The low melting points for the $\mathrm{Zr}-\mathrm{V}$ and $\mathrm{Hf}-\mathrm{V}$ alloys makes them amenable to the now well developed techniques of melt spinning and amorphous powder and filament production. Melt spun ribbons could be plated with copper, placed into the proper application (e.g. magnet winding) and then heat treated to produce the 
desired superconducting properties.

Amorphous powders and filaments of $\mathrm{Zr}(\mathrm{Hf})-\mathrm{V}$ might be valuable starting materials for the construction of composites. The amorphous powder or filaments could be mixed with $\mathrm{Cu}$ powder and extruded into a wire. The ductile nature of the glassy metals would likely lead to the formation of very fine filaments upon deformation. Upon crystallization, the material goes from the nonequilibrium glassy phase to the equilibrium phases hcp $\mathrm{Zr}(\mathrm{Hf})$ and $\mathrm{Zr}(\mathrm{Hf}) \mathrm{V}_{2}$. With a proper choice of heat treating parameters it may be possible to produce a very fine grain structure. From the work on A-15 composites fine filaments and small grain sizes are of crucial importance in obtaining high critical currents [5-7]. Starting with amorphous powders or filaments it may thus be possible to produce microstructures not obtainable by standard metallurgical techniques.

ACKNOWLEDGEMENTS - I am pleased to acknowledge many valuable discussions with Profs. W. L. Johnson and P. Duwez. 


\section{REFERENCES}

* Work supported by Department of Energy Contract No. DE-AC03-76ER00822.

1. B. T. Matthias, V. B. Compton, and E. Corenzwit, J. Phys. Chem. Solids $19,130(1961)$.

2. K. Inoue, K. Tachikawa, and Y. Iwasa, Appl. Phys. Lett. 18, 235 (1971).

3. B. S. Brown, J. W. Hafstrom, and T. E. Klippert, J. of Appl. Phys. 48, $1759(1977)$.

4. For $16 \times 10^{18}$ Neutrons $/ \mathrm{cm}^{2} \quad \Delta T_{c}\left(V_{2} \mathrm{Hf}\right)=5 \%, \Delta T_{c}\left(\mathrm{Nb}_{3} \mathrm{Al}\right)=23 \%$ $\Delta \mathrm{T}_{\mathrm{c}}\left(\mathrm{PbMo}_{6} \mathrm{~S}_{7}\right)=61 \%$ and $\Delta \mathrm{T}_{c}\left(\mathrm{SnMo}_{5} \mathrm{~S}_{8}\right)=51 \%$.

5. J. Bevk, F. Habbal, C. J. Lobb, and J. P. Harbison, Appl. Phys. Lett. 35, $93(1979)$.

6. S. Foner, E.J. McNiff, Jr., B. B. Schwartz, R. Roberge, and J. L. Fihey, App1. Phys. Lett. 31,853 (1977).

7. J. D. Ver hoeven, D. K. Finnemore, E. D. Gibson, J. E. Ostenson, and L. F. Goodrich, App1. Phys. Lett. 33, 101 (1978).

8. W. L. Johnson, S. J. Poon, J. Durand, and P. Duwez, Phys. Rev. B, 18, $206(1978)$.

9. B. M. Clemens, W. L. Johnson, and J. Bennett, submitted to J. of App 1. Phys. (1979).

10. E. A. Kramer, W. L. Johnson, and C. Cline, submitted to Appl. Phys. Lett. (1979). 
11. P. Duwez, Progress in Solid State Chemistry, (Pergamon Press, 0xford), 3,377 (1966).

12. D. E. Polk, C. E. Dube, and B. C. Giessen, Proc. Third Int. Conf on Rapidly Quenched Metals, (Ed. by B. Cantor, British Metals Society, London, I, 220 (1978).

13. J. T. A. Pollock, R. Shull, and H. C. Gatos, Phys. Stat. Sol. (a) 2, 251 (1970).

14. W. Silvert and A. Singh, Phys. Rev. Lett. $\underline{28}, 222$ (1972).

15. P. Duffer, S. G. Sankar, V. U. S. Rao, R. L. Bergver, and R. Obermyer, Phys. Stat. Sol. 31, 655 (1975).

16. M. Hansen, Constitution of Binary Alloys, (McGraw-Hill, New York 1958).

17. H. Hillmann and H. R. Hilzinger, Proc. Third Int. Conf. on Rapidly Quenched Metals, (Ed. by B. Cantor, British Metals Society, London, 1, 22 (1978). 